\title{
Expression of inhibitory receptors on CD4+ and CD8+ T cells from healthy Colombian donors
}

\author{
Alejandra Rico- Lombana ${ }^{1}$, Jose Mateus ${ }^{1}$, Paola Lasso ${ }^{1,2}$, John Mario González ${ }^{3}$, \\ Concepción Judith Puerta ${ }^{2}$, Adriana Cuéllar ${ }^{1 *}$ \\ ${ }^{1}$ Grupo de Inmunobiología y Biología Celular, Facultad de Ciencias, Pontificia Universidad Javeriana, Bogotá, Colombia. \\ ${ }^{2}$ Laboratorio de Parasitología Molecular, Facultad de Ciencias, Pontificia Universidad Javeriana, Bogotá, Colombia. \\ ${ }^{3}$ Grupo de Ciencias Básicas Médicas, Facultad de Medicina, Universidad de los Andes, Bogotá, Colombia. \\ *acuellar@javeriana.edu.co
}

Received: 28-02-2012; Accepted: 31-03-2012

\begin{abstract}
$\mathrm{T}$ cell activation involves positive cellular signals that promote effector functions and negative signals that contribute to the regulation of these responses. These regulatory signals are generated upon activation of receptors on T cells that include CD160, 2B4, Programmed Death-1 and CTLA-4. Objective. To evaluate the expression of inhibitory receptors like CD160, 2B4, Programmed Death-1 and CTLA4 on CD4+ and CD8+ T cells from healthy Colombian donors. Materials and methods. Peripheral blood mononuclear cells from 30 healthy donors from Bogotá (Colombia) were obtained via Ficoll-Hypaque density gradient and cells were stained with specific conjugated antibodies previously titrated. Results. The CD160, 2B4, and Programmed Death-1 inhibitory markers were detected on CD4+ T cells with expression levels of $0.35 \%, 1.04 \%$, and $1.35 \%$, respectively. On CD8+ T cells, these markers were expressed at higher levels: $16 \%$, $8.97 \%$, and $4.3 \%$, respectively. In contrast to the other receptors, CTLA-4 frequency of expression showed no significant difference between CD4+ (1.56\%) and CD8+ (1.53\%) T cells. Frequency of CD160/2B4 and CTLA-4/ Programmed Death-1 coexpression was $0.18 \%$ and $0.09 \%$ on CD4+ cells, and $4.02 \%$ and $0.2 \%$ on CD8+ T cells. Conclusions. This is the first report showing the frequency of inhibitory receptors such as CD160, 2B4, Programmed Death-1, and CTLA-4 on CD4+ and CD8+ T cells from healthy Colombian donors. Our findings serve as a baseline for the analysis and comparison of these receptors in Colombian populations with different disease conditions.
\end{abstract}

Key words: inhibitory receptors, T cells

\section{Resumen}

Expresión de receptores Inhibidores en linfocitos T CD4+ y CD8+ de donantes sanos Colombianos. La activación de células T involucra señales positivas que promueven funciones efectoras y señales negativas que contribuyen a la regulación de la respuesta inmune. Estas actividades regulatorias son generadas por la activación de receptores de las células T e incluyen moléculas como CD160, 2B4, PD-1 y CTLA-4. Objetivo. Evaluar la expresión de los receptores inhibitorios CD160, 2B4, PD-1 y CTLA-4 en células T CD4+ y CD8+ de donantes sanos colombianos. Materiales y métodos. Se obtuvieron células mononucleares de sangre periférica de 30 donantes sanos provenientes de Bogotá (Colombia) mediante gradiente de densidad por Ficoll-Hypaque, las células fueron marcadas con anticuerpos conjugados a fluorocromos previamente titulados. Resultados. CD160, 2B4, y PD-1 presentaron porcentajes de expresión en células T CD4+ de $0.35 \%, 1.04 \%$ y $1.35 \%$ respectivamente. En células T CD8+ estos receptores mostraron niveles de expresión más altos con porcentajes de $16.3 \%, 8.97 \%$ y $4.3 \%$ respectivamente. A diferencia de los otros receptores, CTLA-4 no mostró diferencias entre células T CD4+ (1.56\%) y CD8+ (1.53\%). Los porcentajes de co-expresión de CD160/2B4 y CTLA-4/PD-1 en células T CD4+ fueron de $0.18 \%$ y $0.09 \%$, en células T CD8+ se observaron porcentajes de expresión de $4.02 \%$ y $0.2 \%$. Conclusión. Este es el primer reporte que muestra la frecuencia de expresión de receptores inhibitorios tales como CD160, 2B4, PD-1 y CTLA-4 en células T CD4+ y CD8+ de donantes sanos colombianos. Estos hallazgos representan una línea de base para el análisis y la comparación de estos receptores en la población colombiana con diferentes enfermedades.

Palabras clave: receptores inhibitorios, Linfocitos T. 


\begin{abstract}
Resumo
Expressão de receptores inibitórios sobre linfócitos T CD4+ e CD8+ de doadores saudáveis Colombianos. A ativação de células T envolve sinais positivos que promovem funções efetoras e sinais negativos que contribuem para a regulação da resposta imune. Estas atividades reguladoras são geradas através da ativação de receptores de células T e incluem moléculas tais como CD160, 2B4, PD-1 e CTLA-4. Objetivo. Avaliar a expressão de receptores inibitórios CD160 e 2B4, PD-1 e CTLA-4 em células T CD4+ e CD8+ de doadores saudáveis colombianos. Materiais e métodos. Foram obtidas células mononucleares do sangue periférico de 30 doadores saudáveis provenientes de Bogotá (Colômbia) a partir de gradiente de densidade por Ficoll-Hypaque, as células foram marcadas com anticorpos conjugados com fluorocromos previamente titulados. Resultados. CD160, 2B4, e PD-1 mostraram percentagens de expressão em células T CD4+ de 0,35\%,1,04\% e 1,35\%, respectivamente. Em células T CD8+ estes receptores mostraram níveis de expressão mais elevados com percentagens de 16,3\%,8,97\% e 4,3\% respectivamente. Ao contrário de outros receptores, CTLA-4 não apresentou diferenças entre células T CD4+ (1,56\%) e CD8+ (1,53\%). As percentagens de co-expressão de CD160/2B4 e CTLA-4/PD-1 em células T CD4+ foram de $0,18 \%$ e $0,09 \%$; em células T CD8+ foram observadas percentagens de expressão de 4,02\% e $0,2 \%$. Conclusão. Este é o primeiro relatório que apresenta a frequência de expressão de receptores inibitórios tais como CD160, 2B4, PD-1 e CTLA-4 em células T CD4+e CD8+ de doadores saudáveis colombianos. Estes resultados representam uma linha de base para análise e comparação desses receptores na população colombiana com diferentes doenças.
\end{abstract}

Palavras-chave: receptores inibitórios, linfócitos T.

\section{Introduction}

The outcome of the immune response is largely defined by the predominant microenvironment at the moment of $\mathrm{T}$ cell activation. This activation, upon antigen recognition, involves signals that promote effector functions and negative signals that contribute to the regulation of cellular immune responses. In general, on T cells both signals are generated by the interaction of surface molecules with their ligands on antigen presenting cells (APCs) or soluble molecules in the microenvironment. Molecules like CD160, 2B4, Programmed Death-1 (PD-1), and Cytotoxic T- lymphocyte Antigen 4 (CTLA-4), have been identified as inductors of negative signals, which regulates the activation events of CD4+ and CD8+ T cells (1).

In chronic infection, the phenomenon of $\mathrm{T}$ cell clonal exhaustion has been described as a progressive loss of effector functions. This process seems to be caused by antigen persistence and usually begins with the reduction of the proliferative potential, as well as a decrease in the production of interleukin 2 (IL)-2, followed by a reduction of tumor necrosis factor alpha (TNF- $\alpha$ ) and gamma interferon (IFNg) production $(2,3)$. Of special interest, molecules that induce negative signals as a regulatory mechanism during the lymphocytic activation increase their expression on $\mathrm{T}$ cells entering in such a dysfunctional state. Moreover, the co-expression of two or more inhibitory receptors is associated to clonal exhaustion in both CD4+ and CD8+ T cells $(4,5)$. Nonetheless, expression data of these molecules in $\mathrm{T}$ cells from clinically healthy individuals are scarce and limited to certain human populations.

As a previous step to studying the expression of these molecules in Colombian patients with chronic infections, tumors or autoimmune diseases, herein we evaluated the frequency of CD4+ and CD8+ T cells expressing inhibitory receptors like as CD160, 2B4, PD-1 and CTLA-4 in healthy Colombian donors.

\section{Materials and methods}

\section{Study population}

All individuals enrolled in the study were clinically healthy volunteers who signed the informed consent form. Thirty individuals from Bogotá (Colombia), 67\% female and 33\% male, between 25 and 46 years of age old were included. This study was approved by the Research and Ethics Committee of the School of Science at Pontificia Universidad Javeriana, Bogotá (Colombia).

\section{Inhibitory receptors on $\mathbf{T}$ cells}

To separate peripheral blood mononuclear cells (PBMCs) by Ficoll-Hypaque gradient (Sigma- Aldrich, St. Louis, MO, USA), approximately $15 \mathrm{ml}$ of peripheral blood was obtained from all individuals by venipuncture with heparinized tubes. To evaluate the expression on inhibitory receptors on CD4+ and CD8+ T cells, PBMCs were adjusted to $1 \mathrm{x}$ $10^{6}$ PBMCs per tube and stained with anti CD3-PECy5, anti CD4-APCH7, anti CD8-AF700, anti CD160-AF647, anti 2B4-FITC (BD Bioscience, San Diego, CA, USA), and anti PD1-FITC (BD Bioscience), for 30 minutes at $4{ }^{\circ} \mathrm{C}$ in darkness. Intracellular CTLA-4 was detected in PBMCs permeabilized and fixed with the commercial kit Citofix/ Citoperm (BD Bioscience) according to the manufacturer's instructions and stained with anti CTLA-4-APC (BD Bioscience) during 30 minutes at $4{ }^{\circ} \mathrm{C}$ in darkness. At least $50,000 \mathrm{CD} 8+\mathrm{T}$ cells were acquired for the analysis by using FacsAria I flow cytometer (BD Immunocytometry 
Systems, San Jose, CA, USA), in all cases a greater number of CD4+ T cells was acquired. The fluorescence minus one (FMO), was used to determine potential interference of the fluorochromes panel and as a negative control of marker expression. The data files were analyzed using FlowJo 7.6.1 software (Tree Star. Inc. Ashland, OR, USA).

\section{Statistical analysis}

A descriptive analysis of data, including the frequency of CD4+ and CD8+ T cells expressing the inhibitory receptors was carried out. The values were expressed as medians and ranges. The Mann-Whitney $\mathrm{U}$ test was used to determine differences among groups and differences were considered significant when $p<0.05$ using the GraphPad Prism 5.0
Statistical software (GraphPad Software, Inc, La Jolla, CA, USA).

\section{Results}

\section{Expression of inhibitory receptors on CD4+ and CD8+ T cells}

The expression of the inhibitory receptors was measured on $T$ cells. The cells were selected based on the presence of unclustered singlets according to the size and complexity parameters. On this last population, the $\mathrm{CD} 3+\mathrm{CD} 4+$ and CD3+CD8+ T cells were selected (Figure 1A) and finally, the expression of CD160, 2B4, PD-1 and CTLA-4 was analyzed (Figure 1B).
A.
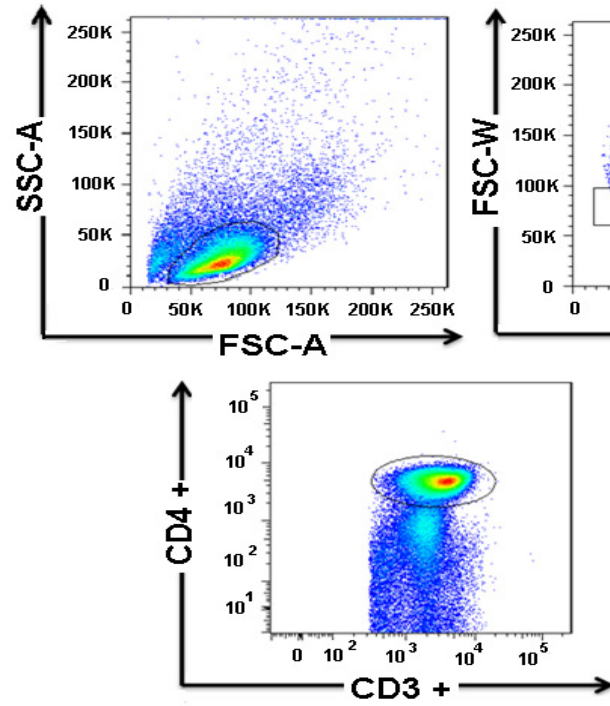
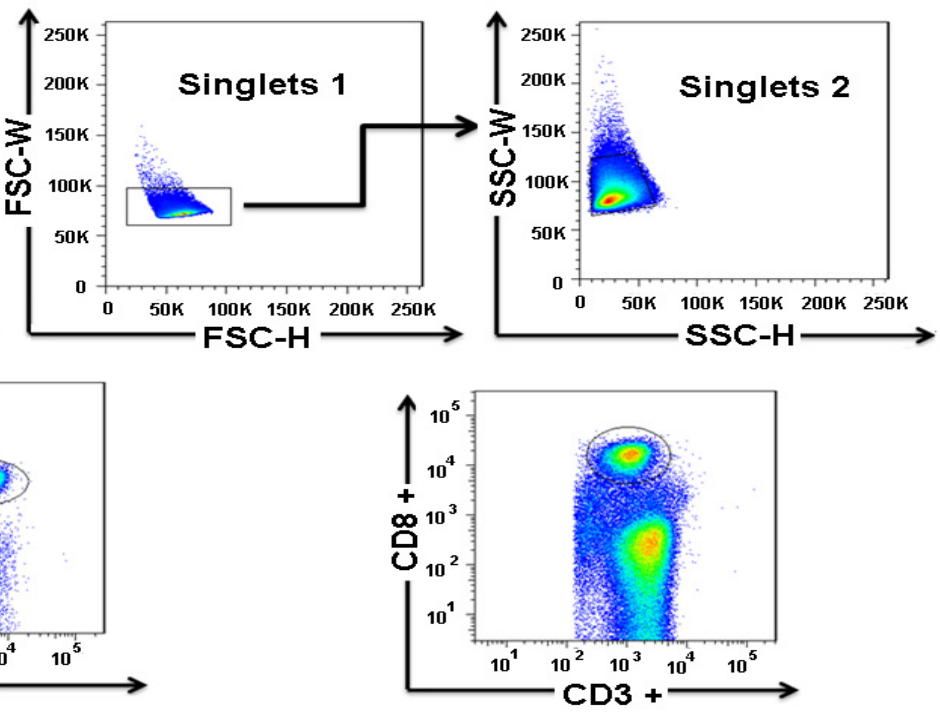

B.
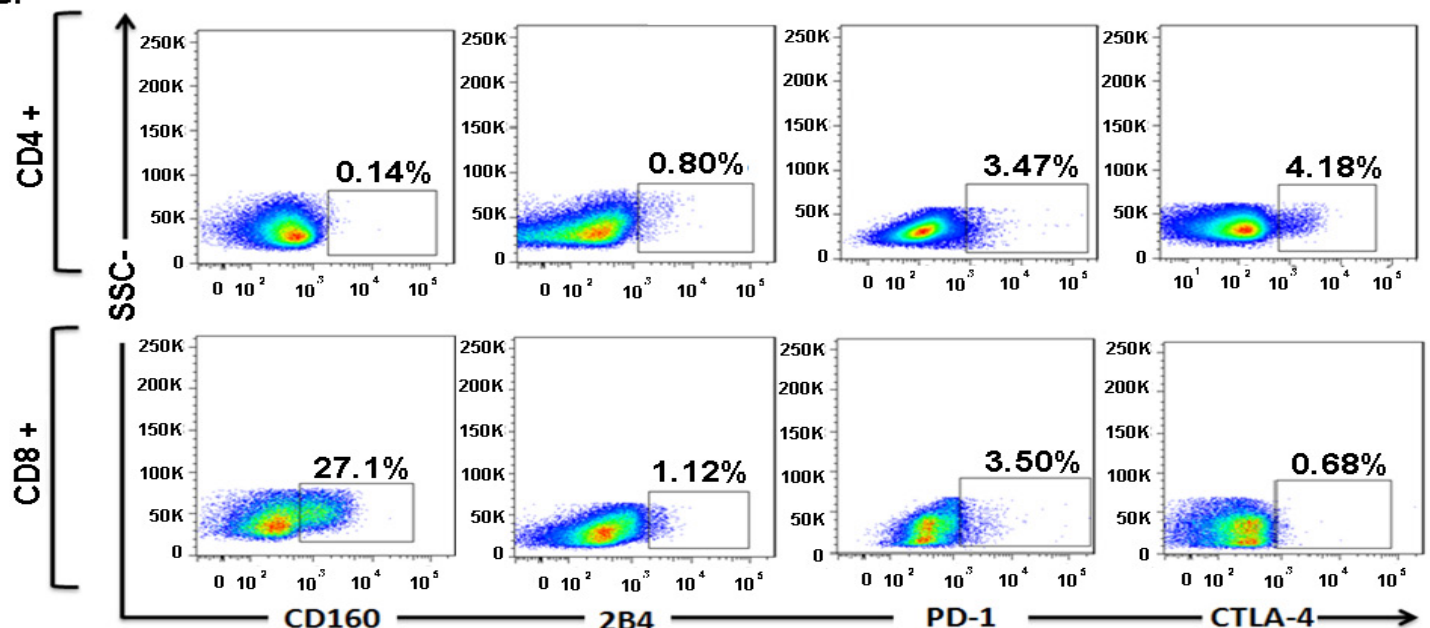

Figure 1. Selection of the population of interest. A) Representative flow cytometry dot plot for the selection of T cells showing singlets and the presence of $\mathrm{CD} 3+\mathrm{CD} 4+\mathrm{T}$ cells and $\mathrm{CD} 3+\mathrm{CD} 8+\mathrm{T}$ cells B) Representative flow cytometry dot plot of CD4+ and CD8+ T cells expressing inhibitory receptors (CD160, 2B4, PD-1 and CTLA-4). 
CD160 expression on CD4+ T cells ranged from $0.04 \%$ to $3.51 \%$ (median $0.35 \%$ ), and from $4.38 \%$ to $42.9 \%$ (median $16.3 \%$ ) on CD8+ T cells. A significant difference, $p<0.0001$, was found when both populations were compared (Figure 2A). The expression of $2 \mathrm{~B} 4$ on CD4+ and CD8+ T cells ranged from $0.16 \%$ to $4.54 \%$ (median $1.04 \%$ ) and $0.74 \%$ to $67.2 \%$ (median $8.98 \%$ ), respectively. A significant difference $(p<0.0001)$ was noted between both T cell subsets (Figure 2B). The expression of PD-1 was detected on CD4+, and
CD8+ T cells with ranges from $0.28 \%$ to $4.6 \%$ (median $1.35 \%$ ), and $0.33 \%$ to $21.1 \%$ (median $4.3 \%$ ), respectively. A significant difference between CD4+, and CD8+ T cells $(p<0.0001)$ was observed (Figure 2C). Percentages of CD4+, and CD8+ T cells expressing intracellular CTLA-4 varied from $0.23 \%$ to $26.9 \%$ (median $1.57 \%$ ), and from $0.29 \%$ to $4.18 \%$ (median $1.54 \%$ ). No difference was detected between the frequency of CD4 and CD8 T cells expressing this marker (Figure 2D).
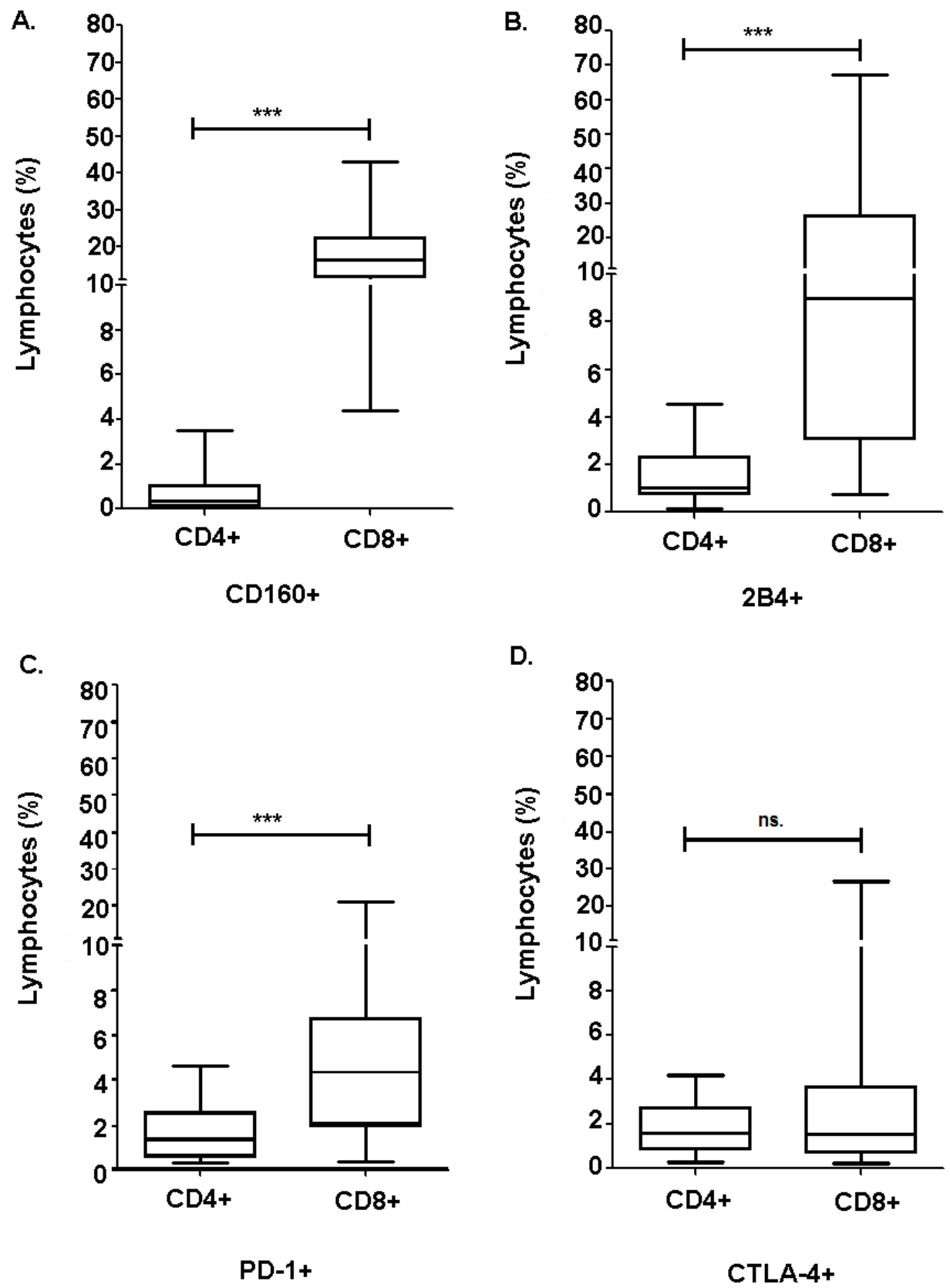

Figure 2. Expression of inhibitory receptors on CD4+, and CD8+ T cells from healthy donors. A) Percentage of CD4+ and CD8+ T cells that expresses CD160. B) 2B4. C). PD-1 and D) CTLA-4 on CD4+ and C8D8+ T cells $* * *(p<0.0001)$. 


\section{Co-expression of CD160/2B4 and CTLA-4/ PD-1 on CD4+ and CD8+T cells}

Studies on chronic infections showed that the co-expression of two or more inhibitory receptors on CD4+, and CD8+ T cells is associated with a dysfunctional state of these cells $(4,6,7)$. In this study, the percentage of CD4+, and CD8+ T cells co-expressing CD160/2B 4 was $0.18 \%$ (range $0.02 \%$ to $0.89 \%$ ) and $4.02 \%$ (range $0.67 \%$ to $34.6 \%$ ), respectively. There was a significant difference between T cells ( $p$ $<0.0001$ ) (Figures 3A and 3B). The co-expression of CTLA-4/PD-1 was $0.09 \%$ on CD4+ T cells (range $0.0 \%$ to $0.27 \%$ ) and $0.2 \%$ (range $0.01 \%$ to $3.5 \%$ ) on CD8+ T cells.
A significant difference of $p<0.02$ was observed when both populations were compared (Figure 3C).

\section{Discussion}

T cells can express a wide variety of co-stimulatory molecules that regulate the initial activation, cell division, and the subsequent generation and maintenance of memory T cells. Nonetheless, these cells also express inhibitory receptors like CD160, 2B4, PD-1 and CTLA-4, which have been implicated in the progressive loss of effector functions. This phenomenon, termed cellular exhaustion, mainly occurs
A.

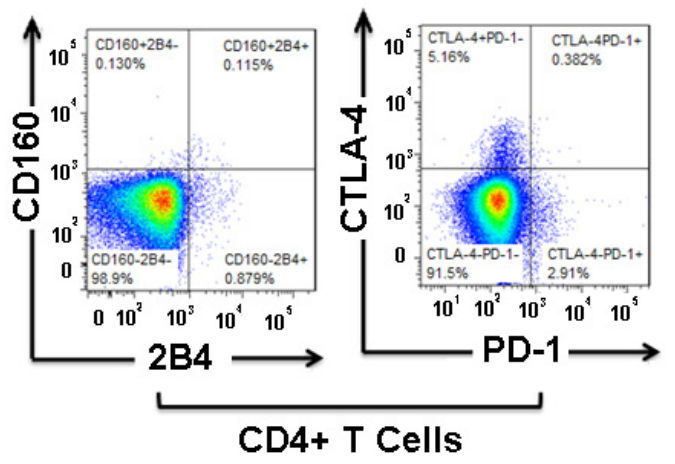

B.

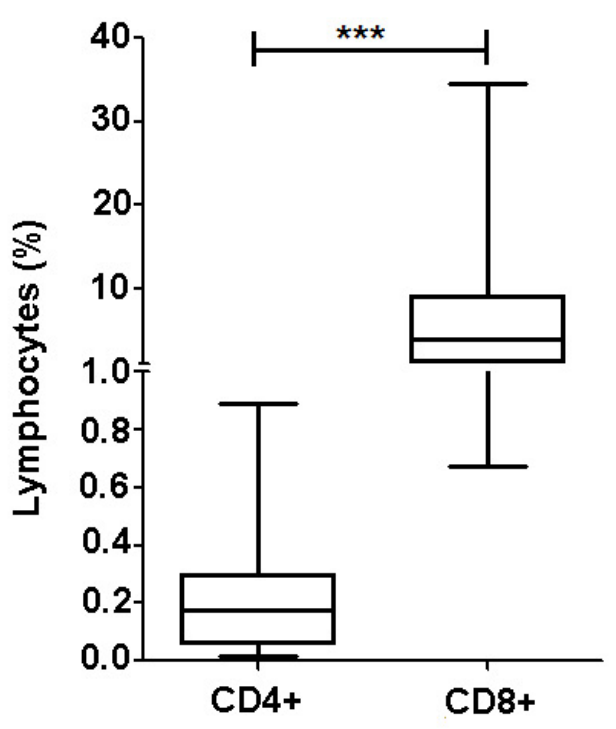

CD160+/2B4+
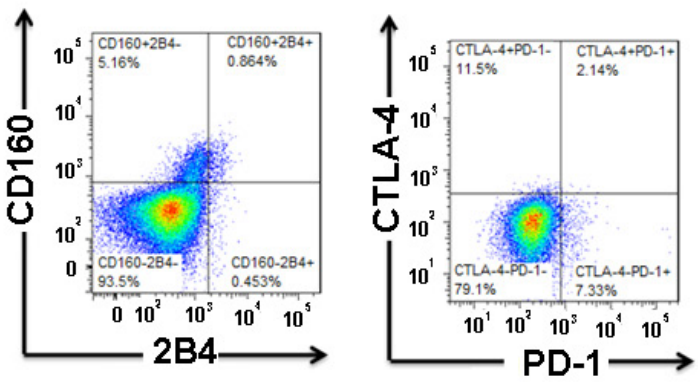

CD8+ T Cells

c.

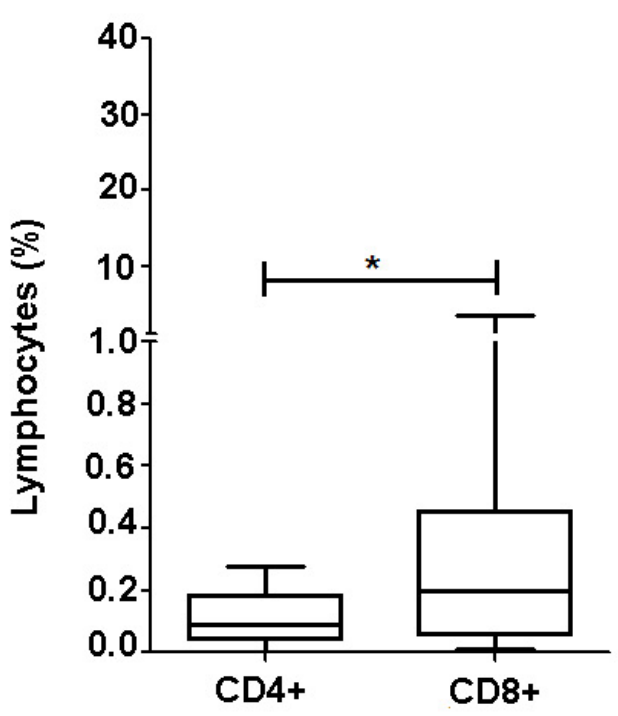

CTLA-4+/PD-1+

Figure 3. Co-expression of CD160/2B4, and CTLA-4/PD-1 on CD4+, and CD8+ T cells from healthy donors. A) Representative flow cytometry dot plot of CD4+ and CD8+ T with co-expression of CD160/2B4 and CTLA-4/PD-1 B) CD160/2B4 and C) CTLA-4/PD-1 $* * *(p<0.0001) *(p<0.0224)$. 
under conditions of pathogen persistence during chronic infections $(8,9)$. The increased expression of inhibitory receptors on $\mathrm{T}$ cells has also been described in tumors and autoimmune diseases (1).

CD160 is a protein mainly expressed on the surface of cytotoxic CD8+ T cells and Natural Killer (NK) cells (10, 11). In this study, it was found that the expression of CD160 on CD4+ $\mathrm{T}$ cells from healthy Colombian donors was lower $(0.35 \%)$ compared to that reported $(8 \%)$ in United States donors (11). This difference could be explained by the fact that both populations are exposed to different environments and stimuli. Indeed, it was reported that CD160 is expressed on CD4+ memory T cells (CD45RA$\mathrm{CD} 45 \mathrm{RO}+)$, and $\mathrm{CD} 4+\mathrm{T}$ cells that have been recently activated (CD45RA+CD45RO-), but it is only barely observed on CD4+ naive T cells (11). On the other hand, the CD160 expression on CD8+ T cells from Colombian healthy donors was similar $(16.3 \%)$ to that reported $(19 \%)$ by Rey et al (2006) in French healthy individuals (13).

Interestingly, 2B4 is a co-stimulatory molecule that can induce both positive and negative signals during the activation of T cells. 2B4 is found in NK cells, monocytes and basophils $(12,13)$. In contrast to the expression on CD4+ T cells, in this study the percentage of $2 \mathrm{~B} 4$ expression on $\mathrm{CD} 8+\mathrm{T}$ cells was highly variable among individuals with values ranging from $0.74 \%$ to $67.2 \%$; similar to other reports in which percentages from $37 \%$ to $79 \%$ were described (13). This marker is more detectable on differentiated CD8+ T cells than in naive $\mathrm{T}$ cells (14).

PD-1, a protein from the immunoglobulin superfamily, is expressed on naive and activated $\mathrm{T}$ cells $(7,15,16)$. This molecule interacts with PD-L1 and PD-L2 ligands and helps to modulate $\mathrm{T}$ cell activation and to limit the duration of the adaptive cellular immune responses (15). Similar to our results $(4.3 \%)$, Song et al., reported frequencies of PD-1 expression on CD8+ T cells of 3.5\% (17) whereas, Sachdeva et al., reported higher frequencies $(7.4 \%)$ in healthy donors (1).

During Human Immunodeficiency Virus (HIV) infection, viral specific $\mathrm{T}$ cells showed a decreased expression of CD160, and 2B4 on CD4+ T cells compared to CD8+ T cells (18). Likewise, our results indicated differences in CD160, 2B4, and PD-1 expression between CD4+ and CD8+ $\mathrm{T}$ cells suggesting that the mechanisms by which both $\mathrm{T}$ cell subsets gradually lose their functional capacity are different (18).

CTLA-4 is a glycoprotein of the family of CD28 costimulatory molecules, which negatively regulates $\mathrm{T}$ cell activation. This molecule has been involved in immune regulation during bacterial and parasitic infections (19-22). Here, it was found that the frequency of CTLA-4 expression on CD4+ and CD8+ T cells was similar and consistent with previous reports, showing percentages from $1.95 \%$ to $2.40 \%$ (23) on CD4+, and of $2.9 \%$ on CD8+ T cells (24).

The co-expression of inhibitory molecules seems critical to induce a dysfunctional state of T cells. In fact, it was observed that cytotoxic cells that express CD160 are mostly found in the 2B4+CD8+ T cell subpopulation (13). Nevertheless, our results showed that the percentages of CD160 and 2B4 coexpression on CD4+ and CD8+ T cells were lower $(0.18 \%$ and $4.02 \%$ ) with respect to those reported in the literature (up to 27\%) [13]. Likewise, the co-expression of CTLA4/PD-1 on CD4+, and CD8+ T cells was low (0.09\% and $0.2 \%)$; so far, there have been no reports of co-expression of these molecules in healthy individuals.

Studies of inhibitory receptor expression on $\mathrm{T}$ cells have been carried out on antigen-specific CD8+ T cells from patients with chronic viral infections coming from different countries (USA, France and Brazil) $(11,13)$. Baitsch et al. showed that the analysis of co-expression patterns of inhibitory receptors increases with $\mathrm{T}$ cell differentiation, and also depends on antigen-specificity, and the differentiation and anatomical location of the T cells (25). Aditionally, the differences found here could be explained by the fact that populations are exposed to different environments and stimuli.

\section{Conclusions}

Our work is the first report showing the frequency of inhibitory receptors like CD160, 2B4, PD-1 and CTLA4 on CD4+ and CD8+ T cells from healthy Colombian population. This finding represents a base line for the analysis and comparison of the expression of receptors in Colombian populations with different disease conditions.

\section{Acknowledgements}

The authors thank at the Colciencias and their program Jóvenes Investigadores e Innovadores "Virginia Gutierrez de Pineda". Special thanks to people who voluntary donated blood samples for this study.

\section{Financial support}

This work was financially supported by Colciencias Research project No. RC-640-2009 and the Vicerrectoria Acádemica, Pontificia Universidad Javeriana project No. 3333. JMG 
received support from the Vicerrectoria de Investigaciones, Universidad de los Andes.

\section{Conflict of Interest}

This research is purely academic, therefore, no conflict of interest with the public or with private enterprise.

\section{References}

1. Crawford A WE. The diversity of costimulatory and inhibitory receptor pathways and the regulation of antiviral T cell responses. Current Opinion in Immunology 2009, 21: 179-186.

2. Shin H, Wherry EJ. CD8 T cell dysfunction during chronic viral infection. Current Opinion in Immunology 2007 , 19: 408-415.

3. Yi JS, Cox MA, Zajac AJ. T-cell exhaustion: characteristics, causes and conversion. Immunology 2010, 129: 474-481.

4. Kassu A, Marcus RA, D'Souza MB, Kelly-McKnight EA, Golden-Mason L, Akkina R,Fontenot AP, Wilson CC, Palmer BE. Regulation of Virus-Specific CD4+ T cell function by multiple costimulatory receptors during chronic HIV infection. The Journal of Immunology 2010,185: 3007-3018.

5. Wherry EJ. T cell exhaustion. Nature Immunology 2011, 12: 492-499.

6. Kaufmann DE, Kavanagh DG, Pereyra F, Zaunders JJ, Mackey EW, Miura T, Palmer S, Brockman M, Rathod A, Piechocka-Trocha A, Baker B, Zhu B, Le Gall S, Waring MT, Ahern R, Moss K, Kelleher AD, Coffin JM, Freeman GJ, Rosenberg ES, Walker BD. Upregulation of CTLA4 by HIV-specific CD4+ T cells correlates with disease progression and defines a reversible immune dysfunction. Nature Immunoogyl 2007, 8: 1246-1254.

7. Bengsch B, Seigel B, Ruhl M, Timm J, Kuntz M, Blum HE, Pircher H, Thimme R. Coexpression of PD-1, 2B4, CD160 and KLRG1 on exhausted HCV-specific CD8+ T cells is linked to antigen recognition and $\mathrm{T}$ cell differentiation. PLoS Pathogens 2010, 6: 1-14.

8. Wherry EJ, Barber DL, Kaech SM, Blattman JN, Ahmed R. Antigen-independent memory CD8 T cells do not develop during chronic viral infection. Proceedings of the National Academy of Sciences of the United States of America 2004, 101: 16004-16009.

9. Day CL, Kiepiela P, Leslie AJ, van der Stok M, Nair K, Ismail N, Honeyborn I, Crawford H, Coovadia HM, Goulder
PJ, Walker BD, Klenerman P. Proliferative capacity of epitope-specific CD8 T-cell responses is inversely related to viral load in chronic human immunodeficiency virus type 1 infection. Journal of Virology. 2007, 81: 434-438.

10. Cai G, Freeman GJ. The CD160, BTLA, LIGHT/HVEM pathway: a bidirectional switch regulating T-cell activation. Immunological Reviews 2009, 229: 244-258.

11. Cai G, Anumanthan A, Brown JA, Greenfield EA, Zhu B, Freeman GJ. CD160 inhibits activation of human CD4+ T cells through interaction with herpesvirus entry mediator. Nature Immunology 2008, 9: 176-185.

12. Eissmann P, Beauchamp L, Wooters J, Tilton JC, Long EO, Watzl C. Molecular basis for positive and negative signaling by the natural killer cell receptor 2B4 (CD244). Blood 2005, 105: 4722-4729.

13. Rey J, Giustiniani J, Mallet F, Schiavon V, Boumsell L, Bensussan A,Olive D, Costelli RT. The co-expression of 2B4 (CD244) and CD160 delineates a subpopulation of human CD8+ T cells with a potent CD160-mediated cytolytic effector function. European Journal of Immunology 2006, 36: 2359-2366.

14. Speiser DE, Colonna M, Ayyoub M, Cella M, Pittet MJ, Batard P, Valmori D, Guillaume P, Liénard D, Cerottini JC, Romero P. The activatory receptor 2B4 is expressed in vivo by human CD8+ effector $\alpha \beta$ T cells. The Journal of Immunology 2001, 167: 6165-6170.

15. Folkl A, Bienzle D. Structure and function of programmed death (PD) molecules. Veterinary Immunology and Immunopathology 2010, 134: 33-38.

16. Sachdeva M, Fischl MA, Pahwa R, Sachdeva N, Pahwa $\mathrm{S}$. Immune exhaustion occurs concomitantly with immune activation and decrease in regulatory $\mathrm{T}$ cells in viremic chronically HIV-1-infected patients. JAIDS Journal of Acquired Immune Deficiency Syndromes 2010, 54: 447-454.

17. Song L ZY, Li, CZ, Wan MB. Natural course of chronic hepatitis B is characterized by changing patterns of programmed death type-1 of CD8-positive T cells. World Journal of Grastroenterology 2010, 7: 618-624.

18. Porichis F, Kwon DS, Zupkosky J, Tighe DP, McMullen A, Brockman MA, Pavlik DF, Rodriguez-Garcia M, Pereyra F, Freeman GJ, Kavanagh DG, Kaufmann DE. Responsiveness of HIV-specific CD4 T cells to PD-1 blockade. Blood 2011, 118: 965-974.

19. Scalapino KJ, Daikh DI. CTLA-4: a key regulatory point in the control of autoimmune disease. Immunological Reviews 2008, 223: 143-155. 
20. Riley JL, June CH. The CD28 family: a T-cell rheostat for therapeutic control of T-cell activation. Blood 2005, 105: 13-21.

21. Anderson KM, Czinn SJ, Redline RW, Blanchard TG. Induction of CTLA-4-mediated anergy contributes to persistent colonization in the murine model of gastric helicobacter pylori infection. The Journal of Immunology 2006, 176: 5306-5313.

22. McCoy K, Camberis M, Gros GL. Protective Immunity to Nematode Infection Is Induced by CTLA-4 Blockade. The Journal of Experimental Medicine 1997, 186: 183-187.

23. Wang XB, Zheng CY, Giscombe R, Lefvert AK. Regulation of Surface and Intracellular Expression of CTLA-4 on Human Peripheral T Cells. Scandinavian Journal of Immunology 2001, 54: 453-458.
24. Frydecka I, Kosmaczewska A, Bocko D, Ciszak L, Wolowiec D, Kuliczkowski K, Kochanowska I. Alterations of the expression of T-cell-related costimulatory CD28 and downregulatory CD152 (CTLA-4) molecules in patients with B-cell chronic lymphocytic leukaemia. British Journal of Cancer 2004, 90: 2042-2048.

25. Baitsch L, Legat A, Barba L, Fuertes S, Rivals JP, Baumgaertner P, Christiansen- Jucht C, Bouzourene H, Rimoldi D, Pircher H, Rufer N, Matter M, Speiser D. Extended co-expression of inhibitory receptors by human CD8 T-cells depending on differentiation, antigenspecificity and anatomical localization. PloS One 2012; 7: $1-10$ 